\title{
Employers' experiences of having a live-in domestic worker: Insights into the relationship between privilege and occupational justice
}

\author{
Roshan Galvaan, BSc OT (UCT), M OT (UCT), PhD OT (UCT) \\ Associate Professor and Head of Division of Occupational Therapy, Department of Health and Rehabilitation Sciences, University \\ of Cape Town, Cape Town, South Africa
}

\section{Liesl Peters, BSc OT (UCT), M OT (UCT)}

Senior Clinical Educator, Division of Occupational Therapy, Department of Health and Rehabilitation Sciences, University of Cape Town, Cape Town, South Africa

\section{Tanita Smith, BSc OT**}

Occupational Therapist, Frere Hospital, Eastern Cape Department of Health

Megan Brittain, BSc. OT**

Occupational Therapist, Bethesda Hospital, Kwa-Zulu Natal Department of Health

Amy Menegaldo, BSc OT**

Occupational Therapist, Livingstone Hospital, Eastern Cape Department of Health

Nicole Rautenbach, BSc OT**

Occupational Therapist, Sterkfontein Psychatric Hospital, Gauteng Department of Health

\author{
Alexandra Wilson-Poe BSc OT** \\ Locum Occupational Therapist, United Kingdom
}

** Students in the Division of Occupational Therapy at the University of Cape Town at the time the study was carried out.

Background: Domestic work is a common form of work in South Africa that is known to place the workers' health at risk. Subsequently, research has focused on this form of work from the workers' perspectives, emphasising the changes needed in employment conditions in South Africa.

Purpose: This paper draws on a research study that explored the lived experiences of employing a live-in domestic worker. The data from this research is used to consider the role that employers' experiences might play in creating particular work conditions for domestic workers.

Methods: The research applied a qualitative, phenomenological design and six participants were purposively selected. Each participant participated in two interviews. A thematic data analysis was initiated between and following the interviews. Subsequently a second level analysis was conducted which stayed close to the first level of analysis but ensured that the essence of the findings were presented with more clarity.

Findings: A single theme "You need them, but they are working on your nerves" and two categories, "caught in a conundrum" and "compelled to be benevolent" emerged. A significant aspect emphasised in the theme and categories was the way that the relationship between the employers and domestic workers left the employers feeling weighed down, which led to tensions that shaped their actions in this work context.

Discussion: Understanding the experiences of employers calls attention to the relationship between the occupational engagement afforded to the employers in relation to their domestic workers. The lived experiences of employers, who are from a privileged part of society, and the possible bearing this has on domestic workers who continue to serve from a marginalised position is highlighted and discussed.

Key words: Employers experiences, Domestic workers, Microagression, Occupational justice

\section{INTRODUCTION}

Perspectives on promoting occupational justice have focused on the unique needs of individuals, advocating that all people should have equal opportunities to participate in varied and meaningful occupations $^{1,2}$ and should be able to autonomously choose the occupations that they engage in $^{3}$. The principles underpinning occupational justice draw particular attention to the needs and rights of marginalised groups, acknowledging that social inequalities influence health ${ }^{4}$ and occupational engagement. Exploring multiple aspects associated with such inequalities allows for a fuller understanding of occupational injustice and its contributing factors.

Domestic workers are recognised as a marginalised group of workers the world over and are known to be denied decent work ${ }^{5}$. Decent work is defined by the International Labour Organisation
(ILO) as being productive work for women and men in conditions of freedom, equity, security and human dignity ${ }^{6}$. Many domestic workers are still excluded from basic, taken for granted, employment conditions such as annual paid leave, minimum wages and maternity protection ${ }^{5}$. A key factor that contributes to the denial of decent work for domestic workers is that the work takes place in private households. In these homes, work is not easily monitored, leaving domestic work unprotected by labour laws ${ }^{7}$. Access to decent work for this sector of workers warrants attention since they represent 1.7 percent of the total employment worldwide and 3.6 percent of all wage employment ${ }^{5}$. Furthermore, globally, $83 \%$ of domestic workers are women. Women are also known to take up the primary role as employers of domestic workers within their homes ${ }^{5}$. This is not surprising since domestic work involves 
the commodification of services that were historically provided by women family members ${ }^{8}$. It is also recognised that many women migrate so that they are able to enter into domestic work and this make them particularly vulnerable ${ }^{7}$. A South African Occupational Therapy study reflected that some domestic workers experience restrictions in their occupational engagement leading to experiences of occupational risk factors such as occupational imbalance and occupational marginalisation'. The study illustrated how the working conditions and employment environment shaped the live-in domestic workers experience of occupational restriction?. The experience of such risk factors and the way that the domestic workers' internalised oppression are known to contribute to occupational injustice ${ }^{9}$. Galheigo ${ }^{10}$ has encouraged Occupational therapists to work with such groups of people, making them visible through raising awareness about them and promoting their social inclusion. While the experiences and perspectives of domestic workers have been studied, little research has focused on the experiences of the employers.

This paper provides a description of employers' experiences of employing live-in domestic workers in South Africa. It illustrates the complex way in which the employers' privileged occupational engagement and their status as a dominant group in society may potentially contribute to oppressive work conditions for domestic workers.

\section{LITERATURE REVIEW}

Social status has been shown to operate at different intensities and across multiple categories of social identity in the relationships between employers and migrant domestic workers in both the United Kingdom and Europe ${ }^{8}$. In these contexts it is known that domestic work allows for the culture and lifestyle associated with the social status of the household to be maintained ${ }^{8,11}$. The presence of a domestic worker, allowed the employer to pursue their lifesyles in a manner most convenient to them ${ }^{8}$. Similarly, in American households where a domestic worker was employed, employers experienced freedom to participate in activities such as leisure, socialising and work ${ }^{12,13}$. However, it has been advocated that a drawback of this situation for employers is that it leaves the employer somewhat dependent on their domestic worker so that they can live the way that they want to". This implies that the employer's occupational engagement depends on the services of the domestic worker.

Reflecting on the experiences of immigrant domestic workers in America, Hondagneu-Sotelo ${ }^{14}$ noted that the employer rebuffs this dependence by taking control through exercising personal distance between herself and the domestic worker. Studies in Brazil $^{15}$ and America ${ }^{12}$ showed that the employers' way of asserting their power was rooted in social class, race and gender hierarchies operating in their relationships with their domestic workers. Likewise, research with domestic workers in South Africa showed that the relationship between the employers and domestic workers influenced how the employer used their positional power ${ }^{16}$. In America, Mendoza ${ }^{12}$ showed that some ways in which employers exercised their positional power was in provision of food for and their delegation of work to the domestic worker. This was seen in the way that food was rationed for the domestic worker, for example only being given an egg for breakfast or left-overs from the children's plates. In a South African research study, the divide in social class was also reinforced by the employers as they directed the times at which the domestic workers were allowed to eat their meals, with whom and where they ate?. However, employers are also known to form familial relationships with domestic workers, depending on what is most suited to them" ${ }^{\prime}$. This was influenced by the quality of the domestic worker's work ${ }^{13}$.

The relationship between employers and their domestic workers is thus complex. Focusing attention on this relationship could facilitate understanding of the multiple factors that contribute to the work conditions of the domestic workers. Research exploring what being an employer of a domestic worker affords the employer and how this is experienced has not yet been conducted in South Africa. The study reported on in this paper, explored the employer's experience of employing a live-in domestic worker within a South African context. The purpose of this paper is to use the data from this study to consider the role that employers' experiences might play in creating particular work conditions for domestic workers.

\section{METHOD}

A phenomenological study was conducted to explore the experiences of employers of live-in domestic workers in the Cape Town Metropole, South Africa. Purposive sampling ${ }^{17}$ allowed for the selection of participants who were information rich; who originated from a diverse population of employers within the Cape Town Metropole reflective of the social landscape of employers and domestic workers in South Africa and who had been an employer of a live-in domestic worker for a minimum of six months. Using snowballing ${ }^{18}$, six participants were recruited. This process involved initially identifying possible participants through people who were known to the researchers ${ }^{19}$. The last five authors thus engaged with known employers of live-in domestic workers or with persons who knew of someone who is or was the employer of a live-in domestic worker. Employers known to these authors, meeting the inclusion criteria for the study, were selected to participate, thereafter further assisting the researchers in the snowballing recruitment process by putting them in contact with other employers of live-in domestic workers, who were willing to consider participating in the study.

Although the researchers tried to recruit both men and women to participate in the study it was found during recruitment that women mostly fulfilled the role of the employer, dealing directly with their domestic worker. The predominance of females as employers is consistent with the profile of employers recognised by the International Labour organisation ${ }^{5}$. The six participants in this study are referred to using pseudonyms to ensure confidentiality. They are Jane, Lucy, Hillary, Anke, Marike and Zandile. Table I presents a profile of employers and their domestic workers. Given that the study focused on their experiences with regards to employing a domestic worker, the domestic workers are also presented in the table.

Table I: Participant Profiles

\begin{tabular}{|l|l|l|l|l|l|l|}
\hline Participant & Jane & Lucy & Hillary & Marike & Anke & Zandile \\
\hline $\begin{array}{l}\text { Participant } \\
\text { race }\end{array}$ & White & White & Coloured & White & White & Black \\
\hline $\begin{array}{l}\text { Domestic } \\
\text { worker's } \\
\text { name \& } \\
\text { race }\end{array}$ & $\begin{array}{l}\text { I) Nandi } \\
\text { Black } \\
\text { 2) Thand } \\
\text { Black }\end{array}$ & $\begin{array}{l}\text { Zyanda } \\
\text { Black }\end{array}$ & $\begin{array}{l}\text { Christine } \\
\text { Coloured }\end{array}$ & $\begin{array}{l}\text { Has } \\
\text { employed } \\
\text { various } \\
\text { people all of } \\
\text { whom were } \\
\text { Black }\end{array}$ & $\begin{array}{l}\text { Meza } \\
\text { Black }\end{array}$ & $\begin{array}{l}\text { Nomhle } \\
\text { Black }\end{array}$ \\
\hline $\begin{array}{l}\text { Work } \\
\text { contract }\end{array}$ & Yes & $\begin{array}{l}\text { No } \\
\text { formal } \\
\text { contract }\end{array}$ & $\begin{array}{l}\text { No } \\
\text { formal } \\
\text { contract }\end{array}$ & Yes & $\begin{array}{l}\text { No } \\
\text { formal } \\
\text { contract }\end{array}$ & $\begin{array}{l}\text { No } \\
\text { formal } \\
\text { contract }\end{array}$ \\
\hline $\begin{array}{l}\text { Employment } \\
\text { period }\end{array}$ & $\begin{array}{l}\text { Nandi- } \\
\text { Tyears; } \\
\text { Thandi }-\end{array}$ & 7 yrs & II years & $\begin{array}{l}\text { A few } \\
\text { months, but } \\
\text { terminated } \\
\text { employment }\end{array}$ & 2 years & $\begin{array}{l}\text { A few } \\
\text { months }\end{array}$ \\
\hline $\begin{array}{l}\text { Socio- } \\
\text { economic } \\
\text { class } \\
\text { (defined } \\
\text { by level of } \\
\text { affluence } \\
\text { and lifestyle) }\end{array}$ & Upper & Middle & Upper & Middle & Middle & Middle \\
\hline
\end{tabular}


Details with regards to race; socio-economic class and the presence of a contract are given to show the differences between the participants and between the participants in relation to their domestic workers. All of the participants were mothers.

The six employers participated in two in-depth interviews, where the following opening question was posed: "What has your experience been of employing your current (or past) live-in domestic worker?" This was followed by prompting questions based on the content of the interview and guided by the research question. During each interview, the researchers remained cognisant of the way in which the participant spoke of their live-in domestic worker, listening and acknowledging the way information was conveyed in order to capture the true essence of the participant's experience. A member checking interview occurred following data analysis. Interviews were digitally recorded and transcribed verbatim immediately after each session. Initial data analysis occurred after the first interview and this informed the questions asked during the second interview with each participant. An inductive, thematic data analysis ${ }^{20}$ was conducted by the researchers, this analysis was refined by the first two authors to ensure that the words used to name the themes and categories best captured the essence of the data.

The latter five authors were undergraduate Occupational Therapy students at the time of the study and self-identified (during bracketing) as being of a similar middle or upper socio-economic class to that of the participants. As children, most of them had lived in homes where domestic workers were employed. Two of the authors had engaged in similar work to that of domestic workers in the South African context when they had been employed as au pairs locally or overseas. The first two authors were also of similar socio-economic class to the participants, employed domestic workers (non- live in) and have children. In order to maintain the credibility of the findings all the researchers reflected on these experiences through peer debriefing discussions and attempted to bracket the experiences ${ }^{21}$ as they engaged in the research process. The researchers were thus able to view the data with a fresh, open perspective. Simultaneously, however, the resonance and dissonance of the data with the researchers' own experience provided an opportunity to critically evaluate the interpretations made during the process of analysis. Member checking, peer debriefing, bracketing and reflexivity ${ }^{21}$ were implemented to ensure trustworthiness of the research findings.

Ethics approval from the University of Cape Town's Human Research Ethics Committee was obtained. Ethical research practices are briefly described below. The researchers obtained signed written informed consent from each participant. Confidentiality was respected by using pseudonyms and concealing any of the participants' details that may have been revealing. Furthermore, all digital recordings of interviews were used for transcription purposes only and these were destroyed upon completion of the study. Non-maleficence was ensured through the researchers clearly communicating the motives for conducting the study with the participants. Additionally the researchers negotiated with participants with regards to the best time and place to conduct the interviews. The researchers ensured autonomy through selfdetermination in which the participants were allowed to choose to participate as well as to withdraw from the study process, if they so wished. This was verbally explained to participants at the start of the research process and was included in the informed consent form. Veracity was ensured since the researchers were aware and cognisant of the manner in which the participants conveyed their experience, in order to report a truthful account of the findings.

\section{FINDINGS}

Two categories reflected in a single theme emerged during the analysis. The categories "Caught in a conundrum" (category I) and "Compelled to be benevolent" (category 2) are described in this section, followed by the theme "You need them, but they are working on your nerves".

\section{Caught in a conundrum}

The first category captures the dichotomous experience of the employer in her employment of a live-in domestic worker, characterised by two conflicting experiences: on the one hand an extremely positive one and on the other an annoyingly negative experience. The experience of this conundrum is captured by Jane:

In a way, although the people who work with me are a support for me, which is why I choose it in another way it's not very peaceful you know, because you're always, you just always got people there with you ... but there are, there are, uh, there are quid pro quo crosses that you have to bear in order to have that (support).

Despite this wish, all the participants expressed the positive nature of their experience of employing a live-in domestic worker and indicated the positive benefits that this relationship afforded them. The quotes by Lucy and Marieke presented below capture this.

But my experiences with her have been ... umm ... great, she has been my son's second mother, she has been absolutely loyal and trustworthy and she has been an enormous support. (Lucy)

but if I could choose, I would choose a live-in domestic worker. My house is always clean and they are always here, on my premises and I don't have to worry if one of them (the children) is sick I can just get done and go to work and they (the live-in domestic worker) is here. (Marieke)

The freedom afforded to the participants through their employment of a live-in domestic worker is what made this experience so positive. All of the participants expressed the freedom from constraints that they experienced as a result of this relationship.

In order for the relationship to afford such freedom the employers structured the working relationship in ways that suited this.

I haven't created a formal structure, I can just say that when I need to say this doesn't work for me or this is the way that this needs to be done, then, then, that is what happens. (Jane)

The liberty to say what goes, afforded Jane the freedom to choose her occupations without bearing the full constraint of household chores or child care. Jane elaborated:

I couldn't do all the things I could do, if I wasn't able to know that if I walk out of here, that there will be somebody there ... But, really for me it is, I couldn't live the life that I live, it does enable me to say at the drop of a hat, ok, I need to go out tonight and I won't be back until 10 or whatever. I don't have to plan that much in advance because l've made it very clear what my expectations were to start with. (Jane)

\section{Lucy and Zandile echoed similar sentiments:}

Um so that has been enormously supportive because I like to do, I often like to do things at the drop of a hat I don't always like to plan very well, so, if I am not planning and I can just go off and do something, or something is happening that somebody has invited us to and we can do spontaneously, that really works for me. Um so, I think I wouldn't have had the freedom that I have or that I have had with (my son) in the last 7 years if she had not been around if I had gone to go hunt for babysitters and worry about whether he is happy, being looked after. (Lucy)

If you, like for me, I'm a working mom and sometimes I have to work till late, so I know that she will be there to take care of my kids and everything. So that support is always there. I am far away from my family, so she is like my mom, or something like my next family that I know I can rely on here in Cape Town, so I don't have any other person to rely on, so I can go away for, for a weekend, I know that she will be there looking after my house as well. (Zandile)

This experience of freedom was tempered by the sacrifice the participants felt they had to make in order to attain it. Participants expressed that they felt invaded because of having an additional person live in their home.

The disadvantage again, is that you've got this person, is not even related to you, but you have to trust them, you know, you don't know them basically, but you have to trust them with your kids and everything and sometimes they tend to over take your house. (Zandile) 
Look it's great having somebody to come in and help you in the morning, but the negative side of that is that there's always somebody in your space, always to have somebody always in your house like a shadow isn't the best thing, sometimes I also want my house to myself. You know? (Hilary)

Participants expressed their intense need to continue to have a live-in domestic worker despite the inconvenience they experienced due to having someone constantly in their space.

that's why I have a live in domestic worker ... because I need someone 24 hours who is available. I don't have a mother here, I don't have a father here and I have no other (family). I'm the only German of my family who is here. So I have a live-in not because I love having people in my house non-stop but because I'm not there and I have to go quickly l've got a horse and other things to do, if I have to quickly get out or if I am very, very sick or whatever I need someone there. (Anke)

For me, for working mom's, you do need a domestic worker, you can try to be a super mom but l'm telling you, it's gonna work on, it's gonna work on you, you won't have time for it all. I mean, even if I do have a domestic worker I get, I still get involved whatever, wherever I can, but I tell you it's not funny, it's like, lots, it's hectic, after work when I come back home, I still wanna spend time with them (the children), I don't want that, when you find your kids saying "mom" to your domestic worker ... but then you really do need them because during the week you won't have time when you come back from work, you are tired you can do there and there and there but you can't start cleaning the house. (Zandile)

Contrasted with this was the way that they valued the companionship with the domestic workers.

... sort of I mean somebody that you are with every-day and no matter what, so you do have that kind of connection, especially if now, because my husband is not there. So when I come back from work, except the kids, there is somebody that I can still talk to, chat, or whatever we can chat about. There is some kind of a relationship. (Zandile)

Experiencing employing a live-in domestic worker as including positive and negative elements, placed the participants in a situation where they felt as if they were caught in a conundrum. Their experiences of their heavy responsibilities as working women and/ or mothers meant that they desperately needed help at home. This in turn meant that, due to the nature of live-in domestic work, they had to tolerate having someone invade their space despite feeling annoyed by this at times.

\section{Compelled to be benevolent}

This category gives voice to the participants' feelings of being generous and altruistic in how they related to their live-in domestic workers. However, they found navigating this relationship in their homes especially challenging.

... you also have to, you are staying with somebody, so you try to make them happy because you don't know whether or what you are doing is making them unhappy or, so it's those dynamics is the kind of, really, makes you, especially now with my kids, is not happy with her, so now I don't know, I'm kind of caught in between the two of them. (Zandile)

So that, there were times when in the beginning I really struggled having her that close, um, I really felt uncomfortable. I never felt like I had my house to myself properly. (Lucy)

Despite wanting this distance, participants fulfilled a mothering role towards their domestic workers while continuing to try and maintain a professional working relationship with her as an employee. Anke illustrated how she fell into a mothering role:

It felt like she needed a mother and I was like, ja, I was her, not her employer only I was like her buddy her friend, her mother, her aunty something she never probably had anyways.

Jane echoed this position ... but now l'm sort of an agony aunt, mother confessor, agony aunt and solver of problems ...

Anke indicated that although the domestic worker was not her child it felt like she was. Many of the participants indicated how they experienced responding to their domestic workers as one of their children and caring for them in this way.

when my daughter wants something like a snack (laughs), it's like I've got two daughters in the house, at times, oh God, (laughs), I just laugh because if I give my daughter something, even if she says she wants biscuits or chips, ok, it's fine, she'll go and ask my daughter "where's mine?" (laughs). So sometimes I just laugh, gosh, how do I handle this situation? (Zandile)

This resulted in a situation where the boundaries of the employer-employee relationship were often blurred.

On many levels we are friends. I mean, I have to be uh, I have to keep rules I suppose, but l'm not stern, they all call me mummy all my staff call me mummy and when they've got problems, they come along. (Jane)

It seemed as if the experience of having someone live in their homes meant that employers began to think of their domestic workers as part of their own families. This made it difficult to know how to be an employer at the same time.

I, I don't see her as a mother, I do, I don't know. How can I describe the way I see her? ... ja, it is complicated, sometimes I forget that I'm the employer here ... For me it's like, it's, it's, sometimes I don't think, I don't think of her as my employee. You, know it's like she is a part of me and the kids. So that's why it's like, we eat with her she stays with us, stays with us in the house, if we are going somewhere, we travel together, you know. So, I am an employer, but on the other hand I don't feel like I am an employer. (Zandile)

Although participants felt burdened by fulfilling this role, they continued to fulfill it. This further complicated the experience of the blurred boundaries of the employer-employee relationship. The participants explained that they continued to do this since they realised that the domestic worker's happiness would impact on her capacity to be available to do the work that the employer needed. This was particularly so when the domestic worker was responsible for looking after the employer's child (or children). The way that socio-economic class influenced the domestic workers' attitudes left the participants perturbed.

Can I just say this about domestics, you know, I um, I have, have questioned why my domestic wouldn't grab the opportunities that I gave her for, um further education and uh, first aid. (Hillary)

The socio-economic class differences between the employers and domestic workers complicated their ways of understanding each other.

I don't know why it is so difficult for this one to have understood the value of further education and training. And we were going to give her that, we were going to give our time to educate her. (Hilary)

"So she would argue sometimes that I cannot understand where she is coming from because it is it is so in my view of ... It is limited, it is stunted, it is like while I wish I could think of a better example for you but I can't ... I mean we are talking about somebody you whose educated in some sort of rural school although her father was a schoolteacher, I mean she had quite a good background, but there were many years when she didn't go to school because it was the time of the war in Zim. In three years that the kids didn't go to school, and when they went to school they were there pretty much all day and all that kind of stuff. There are definitely gaps I mean talk about the things about the universe, about the moon, about basic things that we would have all have learnt about in school that she has no concept of. I mean like she has no idea about the concept of the northern hemisphere and the southern hemisphere that is day and night at different times, and that while somebody is, different time zones are huge gaps in her, in her education that is quite frightening ... And I go Zyanda didn't you do geography? But I did do geography. To what standard? What were they teaching you? There is the moon, there is the Earth. You know, those kind of potential labels worry me. I mean how did she manage to get anywhere? Those are the kind of things you don't forget. (Lucy)

Thus, the employers even experienced trying to be benevolent as contributing to difficulties in relating. 


\section{Theme: "You need them, but they are working on your nerves"}

The essence of the employer's experience of employing a live-in domestic worker in the Cape Town metropole was reflected in the theme "You need them, but they are working on your nerves". The tensions arose from the relationship between their experiences as captured in being "caught in a conundrum" and "compelled to be benevolent". The employers recognised that they depended on the domestic workers, but felt agitated by this relationship too.

Anke described how she tried to understand the layers of disadvantage that her domestic worker had experienced.

She is a victim of her own circumstances, she never had someone who coached her, she never had a proper family, in Malawi the school system is bad.

Similarly Jane shared her appreciation for the challenges that her domestic worker faced after she had a baby and needed to return to work when her baby was three months old. She described how she accomodated the domestic worker.

I wasn't comfortable with the idea of her leaving her three month old in a creche ... so I said bring the baby here.

Jane expressed her admiration for the domestic workers' resilience in saying:

Um, I think it's very sad, because I think it's very unfair or sad that these women are having to leave their children behind, often in the Eastern Cape with their mothers or indeed alone and come and work here to send money back. I think and I also sometimes think it's really sad that, that you know, like I felt with Thandi, gosh, what must it be like to have children who are 7 or 9 or whatever, who aren't with you and then you are looking after someone else's children. I mean life isn't a fair process, but I find that really a sad thing that it has to be like that for them.

But you know, the thing I really admire about these women and I'll tell you something, my experience, my experiences, Xhosa women, really reliable, I mean I admire them cause they bite the bullet and say this is what we got to do to survive. (Jane)

The emotional work associated with being an employer of a live-in domestic worker left the employers feeling weighed down.

It is complicated, sometimes I forget that I'm the employer here, she must, but then again I'm like, oh no, I need to respect this person. So, ja, it's $a$, it's a tricky one ... by that time now, I already have my, I'm just going to tell her as it is whether she cares or not, but then again I have to, like in our culture, respect is a very important thing for older people so. (Zandile)

The emotional aspects of the relationship played out in their daily encounter with domestic workers. Zandile described the emotional threat that she experiences as a mother.

So, they are taking care of the kids, you don't have all the time to spend with your kids, so they are bonding with your kids more than you and they end up taking your house and decide what to do and what the kids need to do and what, what, what, so it ends up being like this person is taking over my, my space and, and sometimes with their moodswings, so you have to know uh-uh she is not in a mood, so try and back off a little bit, so its $a$, its kind of just getting to your nerves a bit.

The employers had to rethink how the domestic worker's occupations could be accomodated within their homes since this was also the place of work for the domestic workers and the domestic workers' home. The following example of Jane's reaction to Nandi cooking tripe in Jane's kitchen illustrates this.

I was like, awww my Lord what is going on? I wanted to vomit and then she said, "but Mummy (refering to Jane) it's my food". And I just said, look Nandi, no disrespect but it's just I can't, I can't do it. I respect what it is that you want to eat but I can't, I can't do this in my house, I mean it really is making me ill. So, we've reached a happy medium

.. I've bought her a like a gas ring and l've said out it goes, so we cook in the free outdoors I just can't do it. (Jane)
Jane had to find a way that made Nandi's food preferences acceptable in her home and resolved that it was a fair compromise to allow Nandi to cook her food outside. She seemed unaware that her manner of engaging may have been disrespectful towards Nandi.

In many ways the employers thus felt compromised in their relationships with their domestic workers. Notwithstanding this, employers were dependent on the freedom afforded to them by employing the domestic workers.

sometimes you just work funny hours, I have to travel, you need somebody reliable that you know will be able to take care of your kids, so, generally I would say it's worth having them. (Zandile)

This placed the employers in the position of constantly balancing the irritation they felt with the fact that they needed, and wanted, the domestic worker as an employee. The essence of this experience is captured in the quote by Lucy:

So I, on the one hand I am very grateful for having her around and very happy to have her around and enormously thankful in some situations when she was around looking after guy but other times aaah I wish I could be rid of her and not have to do it this way, and have a char that just comes in and I don't have to care about.

\section{DISCUSSION}

This discussion offers an interpretation of the relationship that plays out between the employer and domestic worker's occupational engagement. It does this by highlighting how the employers' lived experience affords them an experience of accessing opportunities to participate in occupations, but that that this may contribute to work conditions that contribute to experiences of occupational injustice for domestic workers. Although the domestic workers were not interviewed in this study, previous research has documented the limitations in domestic workers' work conditions ${ }^{5,8,9,14,16}$. It is thus postulated that there might be a relationship between the findings of the study presented in this paper and previous research describing the conditions of occupational injustice experienced by domestic workers.

The findings showed that employers experienced some tensions in how they were supported by their domestic workers, however, their access to domestic workers enabled them to participate with more choice. This participation was possible since employers were able to orchestrate the conditions of employment in a way that prioritised their occupational identities while showing sympathy towards the limitations in the domestic workers' occupational identities. Phelan and Kinsella ${ }^{22}$ suggested that a dialectically oriented appreciation of the way that social and cultural factors shapes occupational identities is useful in interpreting this phenomenon. Acknowledging the dialectical operations of these social and cultural factors highlights that the contextual advantages afforded to the employer occurred against possible costs for the domestic workers. The employers were free to choose the occupations that they engaged in. However, in such work conditions domestic workers have been shown to be at risk of occupational deprivation and illnesses such as depression ${ }^{23}$. In Brazil, elements of race and class inequalities evident in broader society are known to reflect in the power and choices afforded to employers ${ }^{13}$. This echoed with the employers' experiences in this study where they recognised the way that social disadvantages led women to domestic work and limited them from making different choices.

The findings of the current study illustrated how the employers' and live-in domestic workers' participation in occupations were bound to each other. This produces a situation that contributes to the employers experiencing their occupational rights to engage in occupations that they wanted to in a manner of their choosing. Concurrently, it produces conditions that requires a form of servitude from domestic workers so that empoyers are afforded the opportunities that they select. In this way the patterns of participating produced through the lived experiences of employing a live-in domestic perpetuated the social inequality prevalent in South Africa. Social categories of gender, class and race are recognised as shaping different experiences of occupational justice ${ }^{3,24}$. These structural 
factors operate in transactional ${ }^{25}$ ways to construct and constitute individual's experiences of participating in occupations. Identifying the influence of the employer's intersectional identities and privileged access to different opportunities for participation in occupations is new. The way that employers and domestic workers are simultaneously influenced is important for occupational therapists to notice as it illustrates an association between occupational justice and injustice. That is, it points to the way in which participation in occupations shapes the way that groups within society relate to each other and how a relationship may lead to occupational justice for some and injustice for others.

However, the study also showed how domestic workers resistance to being controlled in certain situations influenced the employer's experiences. It has been argued that when domestic workers do not have economic means to express power, they use practices, such as womanhood, to assert their power'. This means that they use their qualities and characteristic associated with being a woman. For instance, in the current study, the employers expressed that they felt that their positions as mothers were, at times, challenged by their domestic workers' actions. The employers may have experienced the domestic workers' assertions of power in these instances. The employers experienced their relationship with their domestic worker in relation to who they were as people, that is their 'being'. This struggle never compromised their 'doing' (that is, participation in occupations) as their actions reflected their claiming freedom. It could thus be argued that the employers subscribed to the human condition, whereby they looked after themselves and their family's wellbeing. The potential influence of this on the live-in domestic worker's human development and wellbeing is not always considered since an awareness of occupational consciousness ${ }^{26}$ was lacking amongst the employers who participated in this study. Through this, the experiences as an employer of a live-in domestic worker may perpetuate the domestic worker's internalised oppression, contributing to the reproduction of occupational injustice.

The employers' experiences of feeling annoyed but wanting the domestic workers assistance, led to their experiences of a variety of emotions. To deal with their experiences, employers were able to draw on the relative positions of power to initiate what may be called micro-aggressions against the domestic workers. Micro aggressions are reflections of worldviews that are filled with biases and assumptions that are strongly inculcated into beliefs, attitudes and behaviours ${ }^{27}$. For example, Lucy's description of her domestic worker's knowledge of geography may have biased her assumptions about the domestic workers' intellectual capacity. Thus the microaggressions is not reflected only in what was said, but in this study was reflected in what the employers did. For example, expecting the domestic worker to always be readily available as the employer made or changed their plans. Deconstructing the underlying meaning of micro-aggressions reveals why this type of communication has such a damaging impact. Micro-aggressions against domestic workers may reinforce their beliefs that they are less valued and confirm that they could or should not expect to autonomously choose what occupations to engage in. One prevalent form of micro-aggressions used was micro-invalidations. Micro-invalidations are "characterised by communications or environmental cues that exclude, negate, or nullify the psychological thoughts, feelings or experiential realities" 27 of marginalised groups. The prejudice, bias and discrimination communicated by the employers about everyday occupations were invisible to them as initiators. This is typical, in that initiators of micro-aggressions often do not realise the impact of their actions ${ }^{27}$. The way these micro-aggressions enacts and sustains the privileged class positions of employers should be recognised as this perpetuated social inequality.

The implications of this understanding for Occupational Therapy practice might include the following:

* Attending to moral and political goals ${ }^{28}$ that demand attention be given to the systemic and relational factors perpetuating occupational injustice such as occupational deprivation ${ }^{23}$ and occupational restriction?.
* Recognition that situations of occupational injustice are produced through experiences of participation in occupations and that understanding how hegemony is reproduced through this is critical

* Creating spaces where narratives can be shared, where collective traumas endured can be acknowledged and reflective dialogue can begin allows for change to be initiated in order to promote occupational justice for all. Since micro-aggressions hold power over the initiators and the targets because of their everyday invisible nature, dialogue that focuses on these occurrences may be reparative. Reparative humanism ${ }^{29}$ suggests that changes in relationships are possible in a divided society.

* Informing employers of the needs expressed by employees and exploring how to support employers in creating conditions for decent work.

* Enabling domestic workers to consider and promote decent work conditions

\section{CONCLUSION}

In contexts where occupational injustice prevails, a dominant social groups' (such as employers) occupational needs may be privileged over marginalised people, contributing to conditions which may perpetuate occupational injustice. The way in which systemic and relational factors frame the use of power during participation in occupations may result in benefiting the promotion of wellbeing of one group over another.

\section{REFERENCES}

I. Wilcock A. An occupational perspective of health. 2nd ed. Thorofare, NJ: Slack, 2006.

2. Wilcock A, Townsend E. Occupational justice. In: Crepeau E, Cohn E, Schell B, editors. Willard and Spackman's occupational therapy. I I th ed. Philadelphia: Lippincott Williams \& Wilkins, 2009: p. 192 -9.

3. Stadnyk R, Townsend E, Wilcock A. Occupational Justice. In: Christiansen C, Townsend E, editors. Introduction to occupation: The art and science of living. 2nd ed. Upper Saddle River, NJ: Pearson Education, 2010: p. 329-58.

4. Braveman B, D B-HJ. From the Desks of the Guest Editors-Social justice and health disparities: An evolving discourse in occupational therapy research and intervention. American Journal of Occupational Therapy, 2009; 63(I):7-12.

5. International Labour Organisation. Domestic workers across the world: global and regional statistics and the extent of legal protection / International Labour Office. Geneva: ILO, 2013. < http://www.ilo. org/wcmsp5/groups/public/---dgreports/---dcomm/---publ/documents/publication/wcms 173363.pdf> 10 October 2014.

6. International Labour Organisation. Mainstreaming Decent work. ILO < http://ilo.org/integration/themes/dw_mainstreaming/langen/index.htm > 10 October 2014.

7. Convention concerning decent work for domestic workers. ILO. $201 \mathrm{l}<$ http://www.ilo.org/dyn/normlex/en/f?p=NORMLEXPUB :I2100:0::NO::PI2100 ILO CODE:CI89 > 10 October 2015.

8. Anderson B. Just Another Job: The Commodification of Domestic Labor 2013. <http://isites.harvard.edu/fs/docs/icb.topicl00I 965. files/Week\%209\%20Readings/Just\%20Another\%20Job_104II 4 rev.pdf $>25$ April 20 I3.

9. Galvaan R. Domestic Workers' Narratives: Transforming Occupational Therapy Practice. In: Kronenberg F, Pollard N, Sakellariou D, editors. Occupational Therapies without Borders - Volume II: Towards an Ecology of Occupation-Based Practices. 2nd ed. Philadelphia: Churchill Livingstone Elsevier, 20II 349-356.

10. Galheigo SM. What needs to be done? Occupational therapy responsibilities and challenges regarding human rights. Australian Occupational Therapy Journal, 20I I; 58(2):60-6.

II. Anderson, B. (2003) 'A Job Like Any Other?'. In Ehrenreich, B. and Hochschild, A. editors. Global Woman. New York: Routledge.

12. Mendoza C. "Boundaries and Borders: Domestics, Employers, and the Production of Difference" Paper presented at the annual meeting of the American Sociological Association Annual Meeting, Sheraton Boston and the Boston Marriott Copley Place, Boston, MA, Jul 3I, 2008.

13. Moras A. "Paid Domestic Work: Resisting an Employer Identity" Paper presented at the annual meeting of the American Sociological Association Annual Meeting, Sheraton Boston and the Boston Mar- 
riott Copley Place, Boston, MA, Jul 3I, 2008.

14. Hondagneu-Sotelo P. Domestica:Immigrant Workers Cleaning and Caring in the Shadows of Affluence. Los Angeles: University of California Press; 200I.

15. Pinho P, Silva EB. Domestic relations in Brazil: legacies and horizons. Latin American research review, 2010; 45(2): 90-II 3.

16. du Preez J, Beswick C, Whittaker L, Dickinson D. The employment relationship in the domestic workspace in South Africa: beyond the apartheid legacy. Social Dynamics, 2010; 36(2): 395-409.

17. Neuman W. Social research methods: qualitative and quantitative approaches. 7th ed: Boston, London: Pearson Education; $201 \mathrm{I}$.

18. Holloway I. A-Z of qualitative research in health care. 2 nd ed. Oxford: Blackwell Publishing; 2008.

19. Miles MB, MH. Qualitative data analysis: An expanded sourcebook. 2nd ed. Thousand Oaks, CA, US: Sage Publications; 1994.

20. Creswell J. Qualitative inquiry and research design: choosing among five approaches. 2nd ed: Sage Publications Inc.; 2007.

21. Lincoln YS, Guba EG. Naturalistic inquiry. Beverly Hills, CA: Sage; 1985.

22. Phelan S, Kinsella E. Occupational identity: engaging socio-cultural perspectives. Journal of Occupational Science. 2009; I6(2): 85-9I.

23. Abrahams T, Majola S, Mshanga D, Turner S. A Pilot Study of the Prevalence of Depression amongst Live-in Domestic Workers within the Cape Metropole: University of Cape Town; 201 I.

24. Angell A. Occupation-Centered Analysis of Social Difference: Con- tributions to a Socially Responsive Occupational Science. Journal of Occupational Science. 20 I4; 2 I (2): I04-I6.

25. Aldrich R. From Complexity Theory to Transactionalism: Moving Occupational Science Forward in Theorizing the Complexities of Behaviour. Journal of Occupational Science. 2008; I5(3): 147-56.

26. Ramugondo EL. Intergenerational Play within Family: The Case for Occupational Consciousness. Journal of Occupational Science. 20I2; 19(4): 326-40.

27. Sue DE. Microaggressions in Everyday life. New Jersey: John Wiley and Sons; $2010, \mathrm{p} 37$.

28. Frank G. The 2010 Ruth Zemke Lecture in Occupational Science Occupational Therapy/ Occupational Science/ Occupational Justice: Moral Commitments and Global Assemblages. Journal of Occupational Science. 20I 2; 19(I):25-35.

29. Gobodo Maikizela P. Reconcilliation: a call to reparative humanism. In: duToit F, Doxtader E, editors. In the balance: South Africans debate reconcilliation. Aukland Park, South Africa: Jacana Media; 2010.

http://dx.doi.org/ I $0 . \mid$ I I 59/23 I 0-3833/20 I 5/v45no la7

Corresponding Author

Roshan Galvaan

Roshan.galvaan@uct.ac.za 